\section{Géneros}

Multidisciplinary Journal of Gender Studies

\section{Hipatia Press}

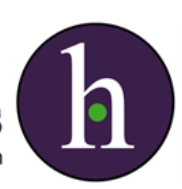

Instructions for authors, subscriptions and further details:

http://generos.hipatiapress.com

\title{
Stereotypical Identities: Discourse Analysis of Media Images of Women in Pakistan
}

Rabia Ali ${ }^{1}$

Saira Batool ${ }^{1}$

1) International Islamic University Islamabad. Pakistan

Date of publication: June $25^{\text {th }}, 2015$

Edition period: June 2015-October 2015

To cite this article:

Ali, R. \& Batool, S. (2015). Stereotypical Identities: Discourse Analysis of Media Images of Women in Pakistan. Multidisciplinary Journal of Gender Studies, 4(1), 690-717. doi: 10.4471/generos.2015.54

To link this article: http://dx.doi.org/10.447/generos.2015.54

\section{PLEASE SCROLL DOWN FOR ARTICLE}

The terms and conditions of use are related to the Open Journal System and to Creative Commons Attribution License (CC-BY). 


\section{Stereotypical Identities: Discourse Analysis of Media Images of Women in Pakistan}

Rabia Ali

Saira Batool

International Islamic University Islamabad. Pakistan

\section{Abstract}

Stereotypical portrayal of women through images and text in the media has been discussed and debated widely across the globe. The area remains relatively under published in the context of the third world especially Pakistan. To fill this gap this paper is an attempt to examine the role of the media in creating gender identities. Data for this study comes from selected English language newspaper namely "THE NEWS". Discourse analysis of text and images - the most common way of producing and transmitting social meaning attached to social realities was employed to interpret of the data. The data reveals that the images and text produced through the media are biased, patriarchal and they reinforce male hegemony and control over women's bodies and their minds. By doing this the media is strengthening the existing power structure of the Pakistani society. The images of women produced are those of victims of violence both domestic and public, sex objects, passive, dependent, weak and engaged in domestic roles. Consequently, standard images of feminity are idealized and normalized in the real world. Such practices act as barrier for women to escape traditional gender roles and expectations. The study argues that such images reinforce stereotypical roles and hence promote gender inequality instead of emancipation.

Keywords: gender stereotypes, discourse analysis, media images, Pakistan 


\section{Identidades Estereotipadas: Análisis del Discurso de las Imágenes de los Media sobre la Mujer en Pakistán}

Rabia Ali

Saira Batool

International Islamic University Islamabad. Pakistan

\section{Resumen}

La imagen estereotipada de la mujer a través de imágenes y texto en los media ha sido discutida y debatida ampliamente en todo el mundo. Este área continua siendo relativamente poco publicada en el contexto del tercer mundo, especialmente en Pakistán. Para llenar este vacía este artículo intenta examinar el role de los media en la creación de las identidades de género. Los datos de este estudio provienen del periódico de lengua inglesa llamado "THE NEWS". El análisis del discurso de los textos y las imágenes -la forma más común de producir y transmitir significado social vinculado a las realidades sociales se utilizó para interpretar los datos. Los datos revelan que las imágenes y textos producidos a través de los media son parciales, patriarcales y refuerzan la hegemonía y control sobre los cuerpos de la mujer y sus mentes. De esta manera los media fortalecen la estructura de poder existente en la sociedad pakistaní. Las imágenes de mujeres que se producen son de víctimas tanto de violencia doméstica como pública, objetos sexuales, pasivas, dependientes, débiles y vinculadas a los roles domésticos. En consecuencia, las imágenes estándar de la feminidad se han idealizado y normalizado en el mundo real. Estas prácticas actúan como barrera para que las mujeres escapen de los roles de género tradicionales y expectativas. El estudio sostiene que este tipo de imágenes refuerzan los estereotipos $\mathrm{y}$, por lo tanto, promueven la desigualdad de género en lugar de la emancipación.

Palabras clave: estereotipos de género, análisis del discurso, imágenes en los media, Pakistán 
$\mathrm{n}$ the contemporary world the media has become an important source of information and entertainment at the global, national and local levels. The media is well known as a supplier of knowledge and as a producer of social realities (Hardt, 2004; Morgan, 2009). It is a carrier of information, ideas, thoughts and opinions. The opinions formed through media play a central role in shaping and reshaping our daily lives. These affect our ideas of who we are and what we could be. We create our identities in relation to the images and text we see and read. The media contents shown to us tend to influence our decision making power and ideological beliefs (England et al., 2011). Media organizations, groups and personnel control the type and nature of media messages that are made public. This includes setting agendas, deciding what is important and to be put on air, the different ways of broadcasting, whom to include and exclude (Carter \& Steiner, 2004).

Throughout the history of mass media, the representation of women in the media has been confiscated (Isanovic, 2006). Since women were and are absent in this medium of communication, portrayals of women and about women are always in relation to men and often "the content of the media distorts women's status in the social world" (Tuchman, 1979, p. 531). Considering this the representation of men and women in the media has been a matter of great concern for understanding the power of media in developing gendered identities. Hence it is essential that media as a power in production of knowledge must also be questioned for its role in the marginalization of women.

Studies have shown that the media 'pictures' often do not reflect the real world (Devereaux, 2003; Giltlin, 1980). Traditional Marxists believe that the images and definitions provided by the media are 'distorted' or 'false' accounts of an objective reality which are modified by the dominated political and economic groups (Curran et al, 1982). Studies have found unnecessary exhibits of the female body and unrealistic images of women in the media (Ullah \& Khan, 2014; Rouner et al., 2003). It has been argued that women are more likely to be exposed as sex objects in media (Morris, 2006). A woman's body is arranged in a way as to attract men. Although the models are beautiful and they perform well to sell the product but the images produced are distortions of reality (Dickey, 2006). Women are portrayed as 
objects, subordinated and as victims that needs to be saved (Collins, 2011; England et al., 2011; Gilpatric, 2010; Lauzen \& Dozier, 2005; Zia, 2007).

It has been argued that the portrayal of women in the news paper, advertisements as well as in TV commercials promote extreme thinness and exposed bodies of women in contrast to the images of men focusing on their faces (Shaheen \& Parveen; Ullah \& Khan, 2014). Such portrayal of women in the media and the expectations to be perfect puts immense pressure not only to have beautiful bodies, but also to look smart and young (Elasmar et al., 1999; Signorielli \& McLead, 1994). This makes women more conscious and choosy about their dressing style as compared to men. Resultantly this stress leads to low self-esteem and eating disorders such as anorexia and bulimia (Glascock, 2001; Rouner et al., 2003; Signorielli \& McLead, 1994).

Besides promoting women as a symbol of sex, the media images also tend to encourage women to act in accordance to the societal expectations and hence reflect the existing power structure of the society. Previous research (e.g. Lang \& Lang, 1971) has revealed that men appear in roles with a higher status and women appear principally in roles having lowerstatus. Representation of men and women in media depicts that women are principally responsible for child-rearing and home-making while men are responsible for income and management. The pages exclusively allocated for women focus heavily on the domestic sphere and represent women in domestic roles such as a perfect cook, a tailor, smart and beautiful. The images of teenage girls are shown as inclined towards passiveness, an obsession for shopping, appearance, and relationships. Such images provide an impression that women are more valued for their submissive and obedient attitude rather than being outgoing and confident (McQuail, 2002).

Women dominate commercials for household cleaning products and goods that involve children and beauty merchandise. Women featured in commercials are most often found in a home setting and playing roles as wives or mothers (Wykes, \& Gunter, 2012). Women are seldom depicted as successful professional, as entrepreneurs and as career oriented individuals in the media (Amber, 2002). The academic professional and intellectual qualities of women are least considered. Their skills, talents and capabilities as equal partners in process of development remain unacknowledged (Shaheen \& Parveen, 2003). Where women do get the opportunity to speak 
on important issues along with men especially in talk shows men often take the hold and dominate women.

This representation of women in the media tends to convey stereotypical and predominantly patriarchal and traditional beliefs. This paper argues that the media images of women are advertised, publicized and promoted for marketing and enhancing profit at the expense their false and unrealistic descriptions. More important issues depicting real day to day lives of women are seldom considered worth representing (Morris, 2006).

In the context of Pakistan where gender has historically been contested the images of women in the media too reflect the larger patriarchal society. Consequently, women are represented in the media as dependant, oppressed and confined within the household domain (Javed, 2005). In addition, to a great surprise despite being an Islamic Republic women are also objectified in the media as physically beautiful and sexy (Ullah \& Khan, 2014; Javed, 2005). This presents a clear separation between the ideology of the nation and the implementation on the ground. These images are misleading because the images of the thin models presented in the media do not represent the majority of the women population of Pakistan.

Taking this as a point of departure the current study is aimed to explore the images of women produced in the media in the context of Pakistan. The images produced in the media have strong influence on how women are portrayed and represented in contemporary Pakistani society. The paper focuses on Foucauldian critical discourse analysis to make its claim. This will help to unveil how meanings are enmeshed in power/knowledge relations that become normalized and naturalized. By doing this we argue that the discursive approaches to entertainment can reveal complex ways about how the media contributes in creating gendered identities. The findings of the paper will help to produce new debates and discourses about representation of women in Pakistani media - an area which remains under published in the context of this part of the world.

\section{Theoretical Framework}

Epistemologically this study is inspired from social constructionism. For social constructionists reality and identity are systematically constructed and maintained through systems of meaning and through social practices. They 
challenge the view that knowledge is created from "the objective unbiased observation of truth (Burr, 2003, p. 3).They believe that the social order in which we perceive the world is in a constant state of flux. Meanings are constructed through interaction between individuals (Bryman, 2008). For social constructionists knowledge is an artifact of culture. Knowledge is constructed through the daily interactions of people in society. Seen in this way language too is a social interaction. This means that meaning is created through language and images depending on how people understand the meanings attached to these as well as relate their selves to construct meaningful identities. The following quote describes it perfectly:

"It is social actors who use the conceptual systems of their culture and the linguistic and other representational systems to construct meaning, to make the world meaningful and to communicate about that world meaningfully to others" (Hall, 1997, p. 25).

Theoretically, the study is inspired from Michael Foucault's (1972) approach to discourse analysis. The term discourse implies social construction of reality as well as a form of knowledge (Fairclough, 1995). According to Foucault "discourse is a group of statements in as far they belong to the same discursive formation" (1972, p. 117). Foucault studied discourse as a system of representation. By 'discourse', Foucault refers to the production of knowledge through language (Foucault, 1980). In Foucauldian terms a discourse is made up of rules that authorize what is the correct form of speech, action or word within its boundaries (Foucault, 1973). For Foucault discourse is a subtle form of social control, discipline and power. Foucault thinks of discourse as a productive technology of social practice which subjects people to forms of power while at the same time providing them with spaces of agency and possibilities of action (Foucault 1981). Foucault wanted to reveal how certain discourses help sustain networks of social meaning which regulate and control people in ways that appear natural (Seale, 2002).

Foucault was interested in discourses because he believed that they play an important role in producing meaning, subjectivity and knowledge. Foucault was of the view that discourse cannot be studied only in the present time but embedded in history. This is because the power components and the historical components create such a tangled knot of shifting meaning 
definitions, and interested parties over period of time. Hence, Foucault's approach to discourse also consider the conditions of its articulation as a contributor to the meanings it produces (1972). He believes that "nothing has any meaning outside of discourse" (Foucault, 1973). The point Foucault was trying to make here was that discourse creates a social context and gives meaning to anything that is spoken about.

Thus the world as an experience is created through language which produces the objects of knowledge. By understanding language, understandings of the world and experiences in the world can be meaningfully understood and reasoned. Realities are constructed through language and these are discourses that produce a system of representation (Foucault, 1982; Hall, 1997). Knowledge of the self and the self in relation to the world emerges in common forms of talk, text, and social practice. Individuals come to know about themselves through such discourses. Discourses thus arrange and normalize the social world and social practices (Alvesson \& Kärreman, 2000).

Discourse analysis is a flexible term. What one is doing is greatly dependent on the epistemological framework being drawn upon (Graham, 2005). It is focused more on the production of knowledge and meaning. Foucault uses discourse analysis to refer to text and analysis of text (1972). However the analysis goes beyond the level of the text and includes an analysis of the broader social context and power relations and tends to be multi disciplinary. Foucouldian discourse analysis can be used to explore the power relations and power effects. It examines the ways in which discourses permeate. It also involves looking at the effects of discourses on, for example, how we experience ourselves and relate to each other.

\section{Methodology}

To explore the representation of women in the Pakistani media an English newspaper "THE NEWS" was selected by using purposively sampling technique. The main reason for selecting this particular newspaper was its reputation as a renowned national newspaper and considering its wide readership across the country. The paper was read thoroughly and critically for the time period of four weeks dating 16 November 2014 to 7 December 2014. This was the time period when the Pakistan Tehreek-e-Insaf (PTI) a 


\section{Ali \& Batool - Stereotypical Identities}

political party was in the midst of their marathon sit-in, in the federal capital attracting national and international media attention. How women were represented in the media during that particular time in history inspired the researchers to explore the larger question of identity when it comes to women's portrayal in the media. While reading the newspapers rigorous notes of what was seen and written were taken. The key research questions were; how are women represented in the newspapers in comparison to men? And how does this representation affect their gendered identities?

The images and texts were chosen by using purposive sampling method. The selected images and text collected were analyzed by using discourse analysis as employed by post structural feminist, which requires interpreting the text within the larger context where it is situated (Foucault, 1972). Hence, this paper employs discourse analysis both as a theory and as a method (Jorgensen \& Phillips, 2002). Special focus was paid to the forms of relationships created through the text (Ullah, 2013) and the context where the text and images were located. The larger social context of Pakistani society remained central to during the analysis process. We started off by looking at the overall representation of women in comparison to men. This included observations on the presence of feminine images, and how they were presented. It also observation on the text including the kinds of news reported and the ways they were reported. The images were repeatedly watched and the texts were read again and again to make sense of the real meaning they conveyed when they were placed in the larger context of Pakistani society.

The selected newspapers were divided into five sections for the systematic discourse analysis. These five sections were Cover page, The City News, Sports News, Political News and Fashion Pages. However Stories and photographs were divided into four categories for purposes of comparison: men-only, women-only, both and neutral. Approximately 95 images in the selected newspaper represented exclusively men and 26 images represented women. The rest of the images represented both gender. In all the mixed images men outnumbered women. After a thorough analysis and re-reading of the four editions of the newspaper, themes were drawn which are being presented in the following section. 


\section{Women's Representation in the Print Media: Recent Discourses}

The current analysis on images of women in print media is divided in to four discourses namely; Public and Private Dichotomy: Defined Boundaries; Stereotypical Portrayals: Traditional Roles and Violence; Sports and political coverage and lastly Beauty Icons: Women Dreams. In what follows each of these discourses will be discussed in detail.

\section{Public and Private Dichotomy: Defined boundaries}

Research has established that media is a powerful force in influencing peoples' perceptions on a variety of issues. The media can be both positive as well as negative in terms of the position and views of women. It is also a powerful mechanism for education and socialization. Speaking from the perspective of gender equality and representation of women it has been found in this study that the portrayal of women in media is narrow and it continually reinforces stereotyped gender roles and assumptions. For example it depicts images that promote women's functions in the private sphere as that of a wife, mother and subordinate to men.

The selected newspapers in this research depicted male domination from the very first page. The cover pages of the newspapers clearly displayed images of men in their roles as bread earners and responsible citizens. Men were depicted as performing important activities like attending governmental meetings, and undertaking management work. They were reported to be protesting for jobs and employment. Women on the other hand were completely ignored on the cover pages. Selected images of women were found in the inside pages of the newspapers and that too were depicted in the advertisement of housing schemes which indicated their association with the private sphere. Females were completely overlooked in management activities in public sphere and directed the reader's attention towards their incapability in these activities. In addition, the images of the women presented were not real. They were covered in heavy makeup and dressed up in elegant way which does not depict the real images of women in the Pakistani society. 


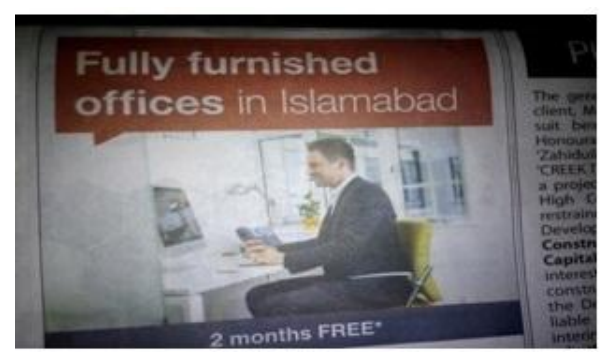

Discourse 1

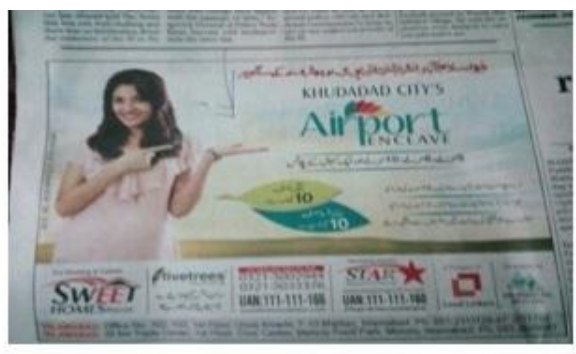

Discourse 2

The above two images (Discourse $1 \&$ Discourse 2) show clear evidence of how media translates a clear public and private dichotomy in the society. It represents and reinforces the accepted notion of womanhood within the private sphere while promotes men in their roles as breadwinners performing more important duties for the nation. Discourse 1 portrays the male figure in his role as breadwinner and involved in professional and technical activities. The man in the picture with a mobile in his hand, a computer at his desk and a smile on his face clearly depicts a masculine figure as a professional. On the other hand discourse 2 clearly depicts that women can be associated with in private domain only. A feminine figure is selected to advertise housing scheme since women are more likely to be associated with the household affairs. The purpose of displaying a beautiful female character here is also to attract customers which are often men. The dominant images and voices of the men in comparison to women in the media reflect the larger patriarchal structure of the Pakistani society and South Asia in general where the image of a woman is confined within the boundaries of home (Lafky \& Duffy, 1996).

Similar findings can be in previous research where women have been represented as submissive, dependent and as victims, sexual objects and so on (Zia, 2007). Men on the other hand have universally been presented in prominent and authoritative roles such as producers, executives, writers, directors, and creators.

Though gender stereotyping is true in various forms in the media, advertising has been reported to take the lead. It has been found that exposure to advertisements employing stereotypical sex roles for women resulted in significantly lower perceptions of women's managerial abilities 
than exposure to advertisements depicting women in professional roles requiring such abilities (Eisend, 2010). According to Eisend (2010) women are being presented as an object for selling commodities in television commercials and newspapers advertisements.

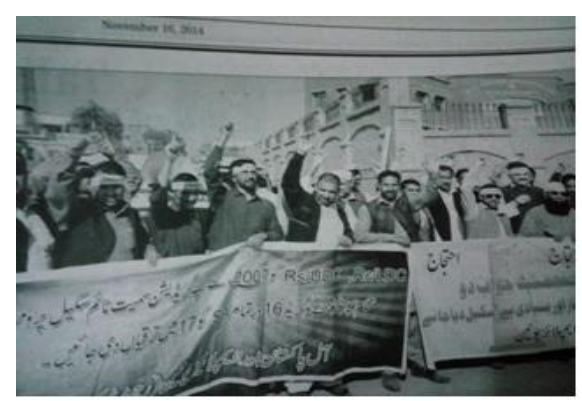

Discourse 3

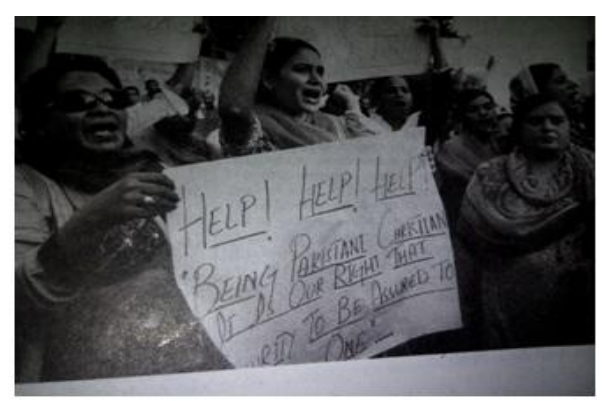

Discourse 4

Besides locating women in the household domain media images also promote gender bias in the society. The above two images (Discourse $3 \&$ Discourse 4) illustrate the gender biased portrayal of men and women in the media. The images depict clear contrast in the action and behavior of the individuals and this difference is embedded in their gender. The men images (Discourse 3) are clear illustration of protest for their rights aggressively. A closer look at the language of the banners shows words like "Ahtejaj" meaning protest. On the other hand the female images (Discourse 4) though too are depicting as acts of protesting but their use of language is totally different. The words on the banners highlight the word "Help" prominently.

This indicates the power of the media. It shows that no matter what the purpose and mood of the protestors may be the media chooses to portray men as assertive and powerful and women as passive and the ones seeking help. This can also be read as males as protectors and women as victims.

Previous research has also established that the media plays a significant role in constructing stereotypical gender roles. Dougherty (2008) for example has demonstrated that media messages about women are often stereotypical i.e., women do not make important decisions or do important things and they are dependent and need men's protection. Women's place is in the house, their energies and intellect must be directed to finding the right 
man and in "keeping" him. The working women are the undesirable exception who must be brought into the marriage fold and made to conform to social norms. Research has also demonstrated that media portray women as a man's silent and docile counterpart (Tuchman, 1979). For feminist scholars, this is often seen as a discourse of patriarchy embedded in ways we come to know society and the self as a woman within society.

\section{Stereotypical Portrayals: Traditional roles \& Violence}

The local news on 'The City Pages' was also found to be predominantly male dominated with few news and images focusing on women. These pages mostly depicted business and economic news as well as news coverage about events in the city. The majority of the pages included in this section were filled with advertisements from educational institutions and universities. Job opportunities and tender notices were prominently highlighted. The pages in this section explicitly depicted stereotypical images of women doing households chores, women in low paid occupations and the news coverage was mostly based on their portrayals as victims of violence.

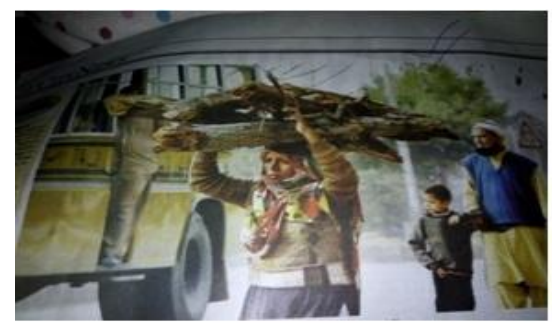

Discourse 5

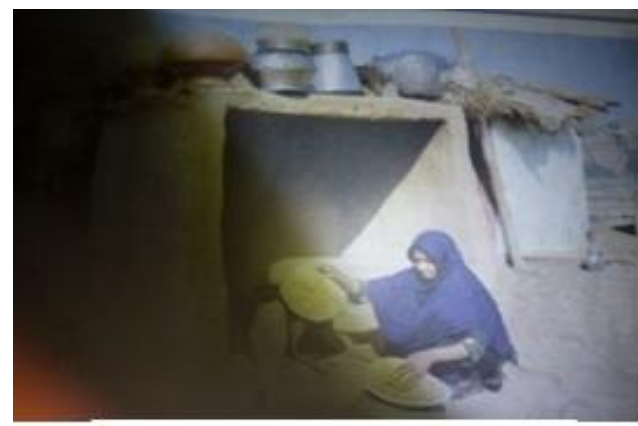

Discourse 5, 6 and 7 clearly portray women as predominantly involved in low-paid jobs and within the private sphere. Similar observations were made by David Gauntlett (2008) who has argued that the typical female in 
our Popular Media (print and broadcast) is submissive, economically dependent, in need of affiliation and more often shown in home bound activities such as cooking, cleaning, knitting, gardening, and collecting wood and fodder etc. (Zia, 2007).

The language used in news coverage for women also predominantly incorporated their stereotypical roles. For example a text read;

"Rural communities especially women are learning skills to become resourceful and be a better helping hand to their families. Women can voice their concerns and find solutions to issues such as the health of their families, alternate income generation options and other issues" (16 Nov, 2014).

This is in accordance with the dominant belief which specifies women to the domestic area and prioritizes traditional duties of women. The centre of all activities designed for women needs to be feminine and can easily be codified in categories such as, "a women dependant on men" , "as an overachieving house wife," "a helping hand of family," "an alternate to income generation entity" and so on.

In addition, the text presented in the newspapers were gender biased and one sided. Women were depicted to be the ones responsible for unsuccessful marriages and domestic issues at home. This is evident from the following text from the newspaper.

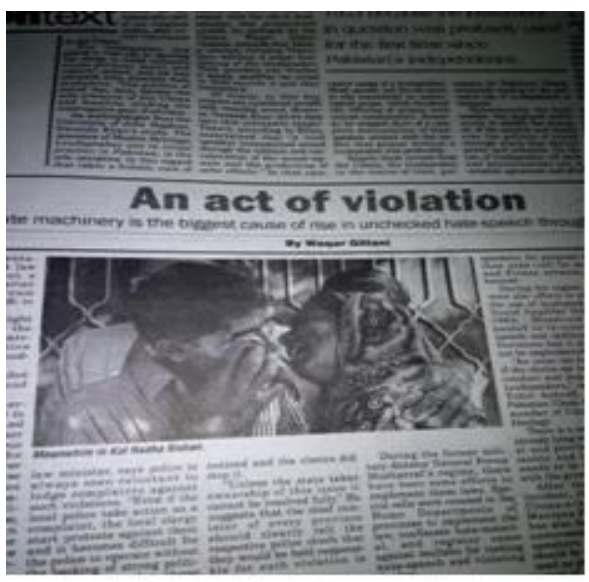

Discourse 8
"Man kills wife, injures another. A woman was quarrelling with her husband on domestic issue when he suddenly started firing on them..." (23 Nov, 2014).

The title of the news as can be read in the image (Discourse 8 ) is "An act of violation." The language in this news clearly shows a one sided pessimistic view embedded in the cultural 
context of the country. This also reflects the larger patriarchal set up of the Pakistani society where women are believed to be the ones to initiate arguments. A famous proverb from Pakistani culture goes like this "choonti $k$ bhi paar nikal aye" (translation: ant having wings which implies that women have become proactive). The title of the news too depicts that prior to any authentic investigation the total act has been termed as against the law.

These cultural constructs establish and promote discourses of what is normal and acceptable. This type of media stereotyping misrepresent women and create a false sense of reality among general public. Thus media helps shape everyday life of individuals. It influences how people think and behave, how they see themselves and other people, and how they construct their own identities. The media creates an impression and also gives judgments without evidence.

Likewise, in reporting news regarding violence against women the newspapers were noted to be using unprofessional language. By doing this they tend to ignore the extremely adverse affect of sensational reporting on the victims and their families. Similar findings have been reported in previous studies (e.g. see Zia, 2007). Attention towards such discourses is important which has also been highlighted in scholarly work. Nancy Berns (2001) is of the view that analyzing popular representations of social problems is important because individuals draw on these sources when constructing their understandings of issues such as violence against women.

In addition, the current study found that the newspapers highlighted news which reflected women's roles in vulnerable positions. For instance news was captioned;

"Thrown to the wolves: Increasingly, the poverty stricken households are sending their children to madrassas as in the case 36 girls from Bajaur recovered from Karachi and Bahawalpur" (7 Dec, 2014).

Poverty hits women more than it does men especially in developing countries like Pakistan (Cheema, 2011). The challenges markedly increase when a woman is out of her home. Poverty and hunger force many families to send their children to madrassas (religious schools) which offer free of cost social services and shelter as a survival strategy. Madrassas also offer 
shelter to homeless and abandoned women who are also prone to trafficking (Ali, 2009; Truong, 2006).

Nevertheless, the fact that women are hit most by poverty does not mean that they should be presented as victims and vulnerable. Importantly, instead of portraying women as vulnerable the media can set examples of how women escape poverty. What strategies do they use to survive? What are the support groups being provided to them? These are issues which require the attention of the media which can encourage women to keep going.

Violence against women is another issue often portrayed in the newspapers. Violence is not a phenomenon specific to any one part of the world. This practice is prevalent across the globe and continues to persist as one of the most terrible, systematic and prevalent human rights abuses in the world. The role of media is central to the issue of violence against women. However, unfortunately news and images on violence against women in the media are portrayed only to highlight the role of activists and to create a soft image about the country at global level. The newspapers used in this research were filled with news of violence against women. A caption in the newspaper read:

"Day for the Elimination of Violence against women on $25^{\text {th }}$ International: Violence against women is the human rights violation; violence against women is a consequence of discrimination against women" (23 Nov, 2014).

Though columns like this one apparently attempt to communicate a gender balance perspective however the real situation on the ground is different than what is portrayed in the media. In addition, media is gender biased and patriarchal when it comes to the issue of violence. Rarely would a newspaper or a television show publish or telecast news by focusing on the role of men as perpetuators of violence against women. Women are always central to news related with showing their second class citizenship in Pakistan.

Similar findings about violence against women portrayed through the media have been reported in the literature. Rehman (2009) has reported that discussions on violence against women are universally focused on women. Likewise, according to statistical data from Asian Human Rights Commission (2008), nearly 5000 women are killed in the name of 'honor' 
across the world. Research shows that globally, at least one in three women and girls face some kind of violence in their lifetime. Krug et al. (2002) in World Health Organization World Report on Violence and Health have reported that one of the most common forms of violence against women is that performed by a husband or male partner. According to Amnesty International (1999) women in Pakistan face numerous forms of violence like rape, gang rape, forced marriages, acid throwing, stove burning, customary practices of Karo Kari and Wanni, domestic violence, sexual harassment at workplace, and honor killing. However cases demanding immediate justice for the victim remain pending for months and years and at times people withdraw cases in the mean time because of the threats they receive from the opponent party (Ebrahim, 2007). This clearly indicates that the representation of women in the media has little to do in offering practical solutions to women's problems. Women continue to face discrimination in the Pakistani society.

\section{Sports and Political Coverage}

The Sport pages too were found to be explicitly male centered with little news coverage on images of women and their participation in sports. The images on these pages highlighted male celebrities receiving prizes and playing games. Previous literature also supports this gender biased nature of media regarding women's representation in sports. Such dominant discourses construct and fix males' sense of self as masculine in opposition to women's feminine behavior in sports (Azzarito, 2012). The representation of men in cricket, hockey, football, basketball, and the exclusion of women from these alludes to the dominant masculine discourse of sport: these games are particularly relevant to men's identity formation and universal masculinity (Boyle \& Haynes, 2000).

Likewise, this study found that women politicians were not considered important and worth reporting as men. News coverage of women politicians focused more on character traits and less on their policy arguments. This paper argues that the masculine nature of media consistently creates hurdles and constraints for women politicians. This hegemony of media causes problems because it promotes personal images and characters based on genders rather than focusing on political issues. The most common depiction of women in political news is as agents of glamour. Media focuses 
are on the personal lives and appearance of women politicians. This puts women more and more behind men in the eyes of the media.

Another discrepancy in the way men and women politicians were displayed was related to their speech and how they spoke. According to Carlin and Kelly (2009) the media focuses on "how" a woman said something. It is least concerned with "what" she said. Sometimes if a female politician speaks harshly or is frustrated with media questions, she is called screechy or short-tempered. One of the common media misrepresentations is that social issues or soft news are the only type of policies women are capable to handle. Examples can include: child care, education, environment/green practices and health care.

The media coverage on the female politicians is also concerned with their qualification for the jobs (Alexander \& Andersen, 1993; Lawrence \& Rose, 2009). Media attention to candidates' personal traits is thought to be particularly destructive for women candidates, because that coverage may tend to deemphasize substantive qualifications (Woodall \& Fridkin, 2003). Women politicians are often identified by their marital or family status, whereas men are more often identified by their occupation or position in society (Pantti, 2006). Media coverage also exploits these women's families, criticizing if they will be able to undertake the role of a politician and still be a good mother and raise a family. In comparison men candidates are rarely, if ever, scrutinized for being fathers or questioned if they can balance politics and family (Rinehart, 2010).

Importantly, women are seen on the outskirts of politics. The traditional political culture pushes women away from the real politics, where important decisions are made behind closed doors (Balz, 2006). This makes it difficult for women to get involved. Political practices like this and the negative, stereotypical messages of the media are creating barriers for female politicians to make it to the top level (Pantti, 2006). Also, most of the production of media is in the control of men. This is yet another barrier that makes it difficult for women politicians to receive equal treatment compared to male politicians (Starr, 2009).

\section{Beauty Icons: Women Dreams}

These pages are mostly called fashion pages but also named as "women pages" as they truly depict female images. These pages from the selected 
newspapers were classic examples of stereotypical images including cooking recipes; accessories for babies, home accessories, beauty tips, clothes, shoes, bags collection, as well as medicines for reducing weight are displayed widely. The images of women in advertisements highlighted beautiful bodies and faces, smart clothes, make up and accessories, efficient housewives, loving daughters-in-law, caring mothers, healthy, happy women who are ready to attend to the errands of their spouses and children. Women were portrayed in arrogant mood on these pages. The pages were filled with advice on dieting, sex tips, fashion and the positioning of the body as the most important part of a woman's life.

The portrayal of women in women only pages in itself is a stereotype and such news items reproduce further stereotypes. The appearance of food items here naturalizes the norm that it is the woman who is responsible for the kitchen and for food preparation. It underlines the notion that food preparation is a role belonging to women, and the kitchen belongs to women according to the traditional gender roles assigned to them. The increasing use of photo-shopped images in these newspaper pages adds to unrealistic perceptions of what women look like in real life. The exposure to idealized images of women in magazines can have negative effects on their selfesteem. Our reading of the newspaper images shows that the women portrayed in perfect shapes in the newspapers are unreal representation of women. However, these images have a subtle but sure effect on the expectations of the society (Wood \& Reich, 2006). The following text from the newspaper depicts this well.

"How fantastic is plastic? The obsession with cosmetic surgery has touched Pakistan and it's not restricted to celebrities. Women bring their young, unmarried daughters for nose jobs, ear tucks and most commonly skin lightening. Visual perfection adds value when being considered for a marriage proposal and a crooked nose, protruding ears and most of all, dark skin is not considered 'Socially desirable' in our society" (16 Nov, 2014).

The effect of media on women in real life is also evident from the literature. According to Behm-Morawitz \& Mastro (2008) the most prominent controlling interaction between females and the media is the ideal standard of beauty. Women in media are almost always skinny, white, able 
bodied and young. Therefore, only a limited demographic is represented in the largest form of communication, isolating those women who do not fall under these categories. Not only do most women fail to meet these standards, even the women in the media who represent the standard fail to meet these themselves.

Self-esteem is at the core of these body image issues, which in some cases leads to tragic situations such as anorexia nervosa or attempts to 'rectify' the 'problem areas' with cosmetic surgery (Graydon, 2004). Advertising guides women to attract men by dyeing their hair to look younger, to lose weight and to prepare gourmet meals. Constantly these advertisements emphasize pleasing others, especially men, as central to being a woman, and the message is fortified with the thinly veiled warning that if a woman fails to look good and please, her man might leave (Rakow, 1992; Peirce's, 1990). The following caption in the newspaper supports this,

"A 'chic girl' should have the perfect style with glowing skin, hairs and nails" (30 Nov, 2014).

This corresponds well with the thoughts of Polivy \& Herman (2004) who are of the view that media dictates how the ideal woman is supposed to look. Through digitally enhanced women in advertisements, and the use of exceedingly thin actors, an unattainable mold of the ideal woman is manufactured. Women who do not fit into this mold are under pressure to adjust accordingly. This indicates that women are actually weakened by how they are portrayed in the advertisements (Goffman, 1979). This blatant control of women by the media is internalized by society thus perpetuated into further generations.

According to Wykes \& Gunter (2005) it is often not the image alone that can have an effect but it is the associated ideas, concepts and messages attached to that image that can prove to be damaging. This reflects that the unreal glamorous portrayal of women in media tend to neglect the fact that they are violating the prevailing societal norms. The effects of such a market-oriented exposure can never benefit women in the long run. By presenting stereotypical/traditional portrayals of women, more serious issues remained neglected (Rasool, 1999). 


\section{Conclusion}

The paper highlighted that the images and texts presented in the media are embedded in discourses which are making the experiences of individuals in the light of history and culture. The paper argued that the discourses produced through the media attach certain meanings to gender identity through which we develop understanding of the expected notion of feminity in our cultural context. Thus, the media has the power to create and (re)produce meanings of women identities which then become naturalized and normalized in our daily lives. Subjectivities of gender are then constrained. Thus, defining the media as a realm of discourse, the paper explored how entertainment media simultaneously enables and constrains the identities of women. Specifically, by studying popular newspaper and employing methods of Foucauldian discourse analysis and interpretation the paper highlighted the gendered subjectivities produced through the media.

The research illustrated that how women are represented has great effects on the real images of women in the society. Hence, media affects our ideas of who we are and what we could be. The images and text we encounter in our daily lives through the media shape our identity. The paper also evidenced that portrayal of women in media reflects the larger patriarchal culture of the Pakistani society. It was clearly evident that the text and images produced in Pakistani media are gender insensitive. Importantly, media images reinforce the patriarchal culture in new ways. This indicates that women's stereotypical portrayal in the media has serious implications. When people are repeatedly shown images of women as victims, passive, dependent, weak, sexualized, in domestic roles, they are more likely to accept these images as normal.

\section{References}

Aday, S., \& Devitt, J. (2001). Style over substance: Newspaper coverage of Elizabeth Dole's presidential bid. The Harvard International Journal of Press/Politics, 6(2), 52-73. doi: 10.1177/108118001129172134 Ahmar, T. (2004). "Gender and Media: Pakistan Perspective” SAFMA Regional Workshop Gender and Media in South Asia, Kathmandu, Nepal. www.southasianmedia.net. 
Ali, S. M. (2009, April 7). Development: The human trafficking problem. Daily Times. Retrieved Aug 242010 from www. Dailytimes. com.pk.

Alexander, D., \& Andersen, K. (1993). Gender as a Factor in the Attribution of Leadership Traits. Political Research Quarterly, 46(3), 527-545. doi: 10.1177/106591299304600305

Alvesson, M., \& Karreman, D. (2000). Varieties of discourse: On the study of organizations through discourse analysis. Human relations, 53(9), 1125-1149. doi: 10.1177/0018726700539002

Amber, S. (2002). Portrayal of women in Media. [Unpublished Master's Thesis] Department of Mass Communication, University of the Punjab, Lahore, Pakistan.

Amnesty International. (1999). "Pakistan: Honor Killings of Girls and Women" retrieved 13 December 2006 from http://web.amnesty.org/library/Index/eng ASA330181999.

Asian Human Rights Commission (2008). "Pakistan: Five women buried alive, allegedly by the brother of a minister." Retrieved 15 November 2014 from http://unesdoc.unesco.org.

Azzarito, L. (2012). I've lost my football...': Rethinking gender, the hidden curriculum, and sport in the global context. Inclusion and exclusion through youth sport, 72-86.

Balz, D. (2006). "Clinton is a Politician Not Easily Defined" The Washington Post 30/May/2006, Print.

Behm-Morawitz, E. \& Mastro, D. (2008, Spring). Mean girls? The influence of gender portrayals in teen movies on emerging adults' genderbased attitudes and beliefs. Journalism and Mass Communication Quarterly, 85, 131-146. doi: 10.1177/107769900808500109

Berns, N. (2001). DEGENDERING THE PROBLEM AND GENDERING THE BLAME Political Discourse on Women and Violence. Gender \& Society, 15(2), 262-281. doi: 10.1177/089124301015002006

Brikse, I. (2004). The role of the mass media in the (re)distribution of power: A comparative report. Report for the project "Mass media in the (re)distribution of power" Community Framework Strategy on Gender Equality (2001-2005).

Boyle, R., \& Haynes, R. (2009). Power play: Sport, the media and popular culture. Edinburgh University Press. 
Bryman, A. (2008). Social Research Methods. 3rd edition, Oxford: Oxford University Press.

Carlin, D. B., \& Kelly, L. W. (2009). Have you come a long way baby? Hillary Clinton, Sarah Palin and Sexism in 2008campaigne coverage, Communication Studies, 60(4), 326 - 343. doi: 10.1080/10510970903109904

Carter, C. \& Steiner, L. (2004). Critical readings: Media and gender. Maidenhead: Open University Press.

Burr, V. (2003). Social constructionism. Psychology Press.

Cheema, I. K. (2011). Trafficking of Women in South Asia. Retrieved December 2014 from URL:

http://www.pu.edu.pk/english/jrh/previous_pdf/Iqtidar\%20Karamat $\% 20$ Cheema.pdf.

Chopra, A. ( 2008). Portrayal of Women in Print Media. Retrieved June 22 2008 from Respondent web site: http://www.responsenet.org/show.detail.asp?id=8655

Collins, R. L. (2011). Content Analysis of Gender Roles in Media: Where Are We Now and Where Should We Go? Sex Roles, 64, 290-298. doi 10.1007/s11199-010-9929-5

Consalvo, M. (1998). Hegemony, domestic violence, and Cops: a critique of concordance. Journal of Popular Film and Television, 26(2), 62-70. doi: 10.1177/0886260502017005001

Curran, J., Gurevitch, M., \& Woollacott, J. (1982). The study of the media: Theoretical approaches. In J. Curran, M. Gurevitch, \& J. Woollacott (Eds.), Culture, society and the media (pp. 11-29). London: Methuen. doi: 10.1177/0196859999023004003

Devereaux, E. (2003). Understanding the media. London: Sage.

Dickey, J. (2006). Out of Focus, Journal of the CPBF. The free Press. London: UK

Dougherty, A. (2008). The intersections of women centered media: Funding and the struggle for our human rights. Global Media Journal, 7(13).

Ebrahim, (2007). "Death penalty:"Swara" killings in Pakistan continue". Inter press services news agency. Available on 'http://ipsnews.net/news.asp?idnews=34896retrieved on 8th Jan, 2007. 
Eisend, M. (2010). A meta-analysis of gender roles in advertising. Journal of the Academy of Marketing Science, 38, 418-440. doi: 10.1007/s11747-009-0181-x

Elasmar, M., Hasegawa, K., \& Brain, M. (1999). The portrayal of women in U.S. prime-time television. Journal of Broadcasting \& Electronic Media, 43, 20-35. doi: 10.1080/08838159909364472

England, D. E., Descartes, L. \& Collier-Meek, M. A. (2011). Gender Role Portrayal and the Disney Princesses. Sex Roles, 64:555-567. doi: 10.1007/s11199-011-9930-7

Fairclough, N. (1995). Media discourse. London: Edward Arnold.

Foucault, M. (1972). The Archeology of Knowledge (London: Routledge, $1972 / 1995$ ed, trans R. Sheridan).

Foucault, M. (1973). El orden del discurso. Barcelona: Tusquets.

Foucault, M. (1980). Power/Knowledge: Selected Interviews and Other Writings by Michel Foucault, 1972-77 (Colin Gordon, Leo Marshall, John Mepham \& Kate Soper Trans.). New York: Pantheon Books.

Foucault, M. (1981).The Order of Discourse. In: Young, R. (1981). Untying the text : A post-structuralist reader. Boston: Routledge \& Kegan Paul. 51-78.

Foucault, M. (1982). The Subject and Power. Critical Inquiry. 8(4): 777795. doi: 10.2304/eerj.2014.13.1.26

Gauntlett, D. (2008). Media, gender and identity: An introduction. Routledge.

Gilpatric, K. (2010). Violent female action characters in contemporary American cinema. Sex Roles, 62:734-746. doi: 10.1007/s11199010-9757-7

Giltlin, T. (1980). The whole world is watching. Berkeley: University of California Press.

Glascock, J. (2001). Gender roles on prime-time network television: Demographics and behaviors. Journal of Broadcasting \& Electronic Media, 45, 656-670.

Goffman, E. (1978). Gender Advertisements. Cambridge, MA: Harvard University Press.

Graham, L. (2005). Discourse Analysis and the Critical Use of Foucault. Paper Presented at the Australian Association for Research in 
Education, Annual Conference Sydney. 27 November, $1^{\text {st }}$ December.

Graydon, S. (2004). In Your Face: The Culture of Beauty and You. Toronto: Annick Press.

Grosz, E. (2010). The practice of feminist theory, Differences: A Journal of

Feminist Cultural Studies, 21, 94-108. doi: 10.1215/104073912009-019.

Hall, S. (ed) (1997). Representation: Cultural representations and signifying practices. London: Sage, Open University Press.

Hardt, H. (2004). Myths for the Masses: an essay on mass communication. London: Blackwell.

Hassan, Y. (1995). "The haven becomes hell: A study of domestic violence in Pakistan"

Humaira, P. (1984). Impact of T.V. Advertisements on Housewives. [Unpublished thesis] Department of Sociology, University of the Punjab, Lahore.

Isanovic, A. (2006). Media Discourse as a Male Domain: Gender Representation in the Daily Newspapers of Bosnia and Herzegovina, Croatia and Serbia. In N. M. Bamburac, T. Jusic, and A. Isanovic (eds), Stereotyping: Representation of Women in print Media in South East Europe. Mediacentar Sarajevo.

Javed, T. (2005). A gender writer. (Writes in national English daily 'The News')

Jones, A. Next Time She'll Be Dead: Battering and How to Stop It. Boston: Beacon Press, 1994.

Jorgensen, M. \& Phillips, L. (2002). Discourse Analysis as Theory and Method. London: Sage.

Joseph, A. K. S. (2006). Whose News? The Media and Women Issues. New Delhi: Sage Publications India Pvt Ltd.

Kazi, S. \& Raza, B. (1991). Duality of Female Employment in Pakistan. The Pakistan Development Review. 30(4), 733-743.

Kilbourne, J. (1999). Deadly persuasion: Why women and girls must fight the addictive power of advertising. New York: The Free Press.

Krug, E. G., Dahlberg, L. L., Mercy, J. A., Zwi, A. A. \& Lozano, R. (2002). World Report on Violence and Health. Geneva: World Health Organization. 
Lacey, N. (2000). Narrative and genre: key concepts in media studies. Basingstoke: Macmillan.

Lafky, S., \& Duffy, M. (1996). Looking through gendered lenses: Female stereotyping in

Lahore: Shirkat Gah.

Lang, K., \& Lang, G. (1971). The unique perspective of television and its effects: A pilot study. In W. Schramm \& D. Roberts (Eds.), The process and effects of mass communication (pp. 84-99). Urbana: University of Illinois Press.

Lauzen, Martha M. \& Dozier, David M. (2005). Maintaining the Double Standard: Portrayals of Age and Gender in Popular Film. Sex Roles, 52:437-446. doi: 10.1007/s11199-005-3710-1

Lawrence, R. G., \& Rose, M. (2010). Hillary Clinton's race for the White House: Gender politics and the media on the campaign trail. Boulder, CO: Lynne Rienner Publishers.

McDonell, T. (2003). The cover story. Sports Illustrated, 99(18). Retrieved April 2, 2004, from EBSCO database.

Michell, P. C. N. \& Taylor, W. (1990). Polarizing trends in female role portrayals in UK advertising. European Journal of Marketing, 24(5), 41-49. doi: 10.1108/03090569010003482

Morgan, M., Shanahan, J., \& Signorielli, N. (2009). Growing up With Television: Cultivation Processes In Bryant, J.,\& Oliver, M.B. (Eds.). Media effects: Advances in theory and research (3rd) (pp. 34-49). Hillsdale, NJ: Erlbaum.

Morris, P. (2006). Gender in print advertisements: A snapshot of representations from around the world. Media Report to Women, 34, 13-20.

McQuail, D. (2002). The Media and Lifestyle Editor's Introduction. European Journal of Communication, 17(4), 427-428. doi: 10.1007/BF00289764

Pantti, M. (2006). "Gender, Politics and Media: Challenging Stereotypes, Promoting Diversity, Strengthening Equality." Portraying Politics.

Peirce, K (1990). A feminist theoretical perspective on the socialization of teenage girls through Seventeen magazine. Sex Roles, 73,491-590. doi: 10.1007/BF00289764 
Polivy, J. \& Herman, C. (2004). Socio-cultural idealization of thin female body shapes: An introduction to the special issue on body image and eating disorders. Journal of Social and Clinical Psychology, 23, 1-6. doi: 10.1521/jscp.23.1.1.26986

Rakow, L. (Ed.). (1992). Women making meaning: New feminist directions in communication. New York: Routledge.

Rasool, U. (1999). "Unethical Ads" published in Daily The News, 6.12.99. doi: 10.1046/j.1525-1497.2002.10503.x

Rehman, F. (2009). "Violence against women turning from bad to worse", Retrieved April 20, 2010, from http://www.nation.com.pk/pakistannews-newspaper-daily-englishonline/Regional/04-Sep2009/Violence-against-women-turning-from-bad-to-worse.

Rinehart, Nicholas. "Harvard College Women's Center Sponsors Lecture on Women in Politics ." The Harvard Crimson. N.P., 10/11/2010. Web. 12 Apr 2011.

Ross, K. \&Sreberny, A. (2000) Women in the house: media representation of British politicians. In Sreberny, A. \& van Zoonen, L. (Eds.) Gender, Politics and Communication.Creskill: Hampton Press, 7999.

Rouner, D., Slater, M., \& Domenech-Rodriguez, M. (2003) Adolescent evaluation of gender role and sexual imagery in television advertisements. Journal of Broadcasting \& Electronic Media, 47, 435-454. doi: 10.1207/s15506878jobem4703_7

Bokhari, S. (2012). Group Editor, daily, 'The News'. (English newspaper).

Sardar, F., Mumtaz, N. , Hossein, S. and Mayoux, L. (2005). "Women and Men's Views of Empowerment: Kashf Empowerment Diamonds." Retrieved Nov 2007, from http://www.genfinance.info/Documents/Kashf\%20Empowerme nt\%20Diamonds.pdf.

Seale, C. (2002). Cancer heroics: a study of news reports with particular reference to gender. Sociology, 36(1), 107-126. doi: 10.1177/0038038502036001006

Shaheen, S., Parveen, K. (2003). A study about portrayal of women in mass media. Department of Gender Studies,,University of the Punjab, Lahore. 
Signorielli, N., McLeod, D. \& Healy, E. (1994). Gender stereotypes in MTV commercials: The beat goes on. Journal of Broadcasting \& Electronic Media, 38, 91-102. doi: 10.1080/08838159409364248

Skornia, H. J. (1977). 'The great American Teaching Machine — of Violence Intellect.' P. 347 Cited In 'Introduction Mass Communication (2nd Ed) P253.

Starr, D. (2009). How Toys Teach Children Stereotypical Gender Roles: A Look Inside a Local Toy Store. North Carolina State University. Retrieved from http://www.unc.edu.

Truong T. D. (2006). Poverty, Gender and Human Trafficking in SubSaharan Africa: Rethinking Best practices in Migration Management. Retrieved from URL: http://unesdoc.unesco.org/images/0014/001432/143227e.pdf.

Tuchman, G. (1979). Making news: A study in the construction of reality. New York: Free Press.

Ullah, H. Khan, N. H. (2014). The Objectification of Women in Television Advertisement in Pakistan. FWU Journal of Social Sciences 8(2). 26-35.

Ullah, H., \& Ali, J. (2013). Power on the Pages of Textbooks. Examining Class Hierarchies. Middle Eastern Journal of Scientific Studies. 14(1), 53 - 62. doi: 10.5829/idosi.mejsr.2013.14.1.19499

Ward, M. \& Friedman, K. (2006) Using TV as a guide: associations between television viewing and adolescents' sexual attitudes and behavior. Journal of Research on Adolescence, 16(1), 133-156. doi: 10.1111/j.1532-7795.2006.00125.x

Wood, J. T., \& Reich, N. M. (2006). Gendered communication styles. Intercultural communication: A reader, 177-186.

Woodall, G. \& Fridkin, K. L. (2006). Media Consideration for Women Presidential Candidates, In L. C. Hans (Ed.), Rethinking Madam President: Is America really ready for a woman in the White House? Boulder: Rienner.

Wykes, M. \& Gunter, B. (2005). The media and body image: If looks could kill. Sage.

Zia, A. (2007). Media And Gender: Pakistani Perspective, 16th AMIC Annual Conference June. 25-28, 2007, Singapore. 
717 Ali \& Batool-Stereotypical Identities

Rabia Ali Department of Sociology, International Islamic University Islamabad. Pakistan

Saira Batool Department of Sociology, International Islamic

University Islamabad. Pakistan

Contact Address: Sector H-10, Islamabad, Pakistan

E-mail address: rabi.aly@gmail.com 